\title{
Hush-hushing the whole matter: The UNHCR, Australia, and West Papuan Refugees
}

\author{
Klaus Neumann
}

\begin{abstract}
Between 1962 and 1973, thousands of refugees crossed from the Indonesian-controlled western half of the island of New Guinea into the Australian-controlled eastern half. The United Nations High Commissioner for Refugees (UNHCR) refrained from becoming involved in the issue, and from publicly criticizing the Australian government over its response to West Papuan asylum seekers. In return, the Australian government committed itself to keeping the High Commissioner informed about developments in New Guinea on the understanding that it would provide information on a strictly confidential basis. The article explores the High Commissioner's possible motives for effectively condoning Australia's refugee policies in Papua and New Guinea. It demonstrates the relevance of this historical case study for our understanding of current Australian policies and for evaluating the relationship between the UNHCR and governments.
\end{abstract}

\section{Résumé}

Entre 1962 et 1973, des milliers de réfugiés sont passés de la moitié occidentale de l'île de la Nouvelle-Guinée, contrôlée par l'Indonésie, à la moitié orientale, sous contrôle australien. Le Haut Commissaire des Nations Unies pour les réfugiés (HCNUR) s'est abstenu de s'impliquer dans le problème et de critiquer publiquement le gouvernement australien pour sa réponse aux demandeurs d'asile de la Papouasie de l'Ouest. En échange, le gouvernement australien s'est engagé à informer le Haut Commissaire sur l'évolution en Nouvelle-Guinée à condition que celui-ci fournisse des renseignements de manière strictement confidentielle. L'article s'attarde aux motifs possibles du Haut Commissaire pour avoir efficacement toléré les politiques de l'Australie en matière de réfugiés en Papouasie et en Nouvelle-Guinée. Il démontre la pertinence de cette étude de cas historique pour notre compréhension des politiques australiennes actuelles et pour l'évaluation de la relation entre le HCNUR et le gouvernement.

$\mathrm{T}$ The involvement of the United Nations High Commissioner for Refugees (UNHCR) in the provision of humanitarian assistance during the Kosovo conflict demonstrated that the UNHCR, much like other international organizations, has not been as non-political as it has frequently claimed (and as its statute stipulates). ${ }^{1}$ Gil Loescher's magisterial history of the organization shows that its partiality in 1999 had precedents, and that since its inception in the early 1950s, its approach to refugee crises had regularly been influenced by the interests of governments. ${ }^{2}$ The UNHCR's funding comes almost entirely from voluntary contributions made by individual states, and, as Loescher has pointed out, " $[\mathrm{g}]$ overnments exert leverage on the office by earmarking funds for programmes that are of particular political interest to them." 3 The dependence on the goodwill - and, indeed, the vested interests - of individual governments is further exacerbated by the fact that the UNHCR's major donors comprise only a small proportion of the UN's member states.

While the dependence of international organizations on member governments - and, in particular, those of their principal donors-has been widely acknowledged, little attention has been paid to the minutiae of the relationship between international organizations and member govern- 
ments. So far, no study has been published that investigates in detail the dynamics of the relationship between the UNHCR and a national government. In this article I explore a key chapter in the relations between the UNHCR and Australia. Drawing on Australian government files and UNHCR archival records, I demonstrate how the organization's role in providing, and lobbying for, protection for refugees was compromised by its consideration for Australia's interests.

Australia has long claimed to be among the organization's staunchest supporters. It has been a regular financial contributor, has been one of only a handful of countries offering long-term resettlement solutions, was a long-time member of the UNHCR executive committee, and was one of the first countries to ratify the 1951 Refugee Convention. In recent years it has often been pointed out that the relations between Australia and the United Nations in general, and the UNHCR in particular, have been strained since at least the turn of the century, if not since the election of the Howard government in $1996 .{ }^{4}$ I do not doubt this claim, but would like to question the assumption usually underlying it, namely, that before 1996, Australia was a model member of the United Nations and that the Australian government wholeheartedly embraced the principles guiding the work of the High Commissioner for Refugees.

In the following, I analyze the policies and perceptions of both the Australian government and the High Commissioner and his staff concerning West Papuans seeking Australia's protection in Papua and New Guinea between 1962 and 1973. References to either the prominence of Australia's geopolitical role or the size of the West Papuan refugee flow may be insufficient to warrant this case study. But while providing an in-depth analysis of negotiations that were seemingly of minor importance in the context of Australia's overall relationship with international organizations, and in the context of the UNHCR's overall relationship with members of the United Nations, it throws light on wider issues, such as the subsumation of refugee policy under foreign policy, the dependent relationship between the UNHCR and governments, the costs and benefits of discretion, and the High Commissioner's role in forging relationships with governments and in thereby shaping the organization's approach to particular refugee crises.

\section{Australia and the UNHCR: The Historical Context}

Throughout the debate that led to the establishment of the UNHCR, the Australian government was skeptical about the role the new organization could play and disagreed strongly with some of the sentiments reflected in the draft Convention. ${ }^{5}$ Commenting on what became Article 31 , the Secretary of the Department of Immigration, Tasman Heyes (whose contribution to the work of the UNHCR was later to be recognised with a Nansen medal), wrote:

This article . . . is designed to recognise a right of asylum for persons escaping from persecution; but ... it merely permits unlawful entry, so long as the refugee presents himself without delay to the authorities and 'shows good cause' for his illegal entry. This is obviously designed to meet conditions in Europe where there are frontiers across which a refugee may escape. It would hardly accord with Australia's immigration policy if the Atlantic and Pacific Oceans were to be ranked as frontiers across which asylum should be sought. ${ }^{6}$

Although initially opposed to the idea of putting the draft Refugee Convention to a special conference of plenipotentiaries, Australia was one of twenty-five countries represented at the Geneva conference of July 1951. ${ }^{7}$ The Australian delegation was careful not to highlight Australia's objections, but it was comparatively isolated on account of its opposition to key elements of the draft Convention. Of those represented at the conference, only the United States had as many misgivings about the draft Convention as Australia.

Believing that the Refugee Convention would interfere with their countries' respective immigration laws and suspicious of the newly created international agency, the Australian and United States governments were instrumental in establishing the Intergovernmental Committee for European Migration (ICEM), thereby duplicating some of the UNHCR's functions. During the 1950s and 1960s, Australia admitted more refugees for resettlement through the ICEM than through the UNHCR.

Australia acceded to the Refugee Convention in 1954. The Department of Immigration had dropped many of its initial objections when, much to the surprise of the Australian delegation to the 1951 Geneva conference, contracting states were allowed to opt against making the Convention universally applicable. Australia nevertheless recorded reservations regarding six of the Convention's articles.

Initially, the Australian government dealt with the UNHCR through its permanent mission in Geneva. While the UNHCR nominated refugees for resettlement, it did not supervise their resettlement in Australia. From 1956, the UNHCR was represented in Australia by an Australian, Brigadier Frank Field, albeit on a part-time and largely honorary basis. ${ }^{8}$ He seems to have concerned himself mainly with fund-raising activities; the Australian government, which had been skeptical about the benefits of his appointment, would clearly not have wanted him to monitor its resettlement efforts. 
When Field announced his retirement in 1958, the High Commissioner used the opportunity to propose the establishment of an Australian branch office staffed by a fulltime UNHCR representative. ${ }^{9}$ The High Commissioner wanted his representative to be "responsible for liaison with Government authorities, the coordination of voluntary agencies' activities in the field of refugee re-settlement and fund raising activities in Australia and New Zealand." 10 Australia's Departments of External Affairs and Immigration had little interest in the establishment of such an office, which they seemed to regard as an attempt to meddle in Australia's affairs. ${ }^{11}$ Australia's Minister for External Affairs, Richard Casey, noted with regard to the UNHCR's proposal: "This seems overdoing it-but I suppose it is their affair and not ours-and we can do nothing but agree." 12 In April 1959, the U.S. national Alexander McIver became the first full-time UNHCR representative in Australia.

Within the context of the international refugee regime at the time, Australia was of crucial importance as a final destination for many European refugees. Ordinarily, refugees were resettled in Australia after they had been nominated by the UNHCR or the ICEM and then selected by Australian immigration officers. But from at least 1954, when a Soviet diplomat and his wife defected and formally sought Australia's protection, Australia had also dealt with asylum seekers. During the 1956 Melbourne Olympic Games, dozens of athletes requested political asylum in Australia. In the late 1950s and early 1960s, ship jumpers and stowaways from Eastern European countries and from China, and three Portuguese naval deserters, similarly sought asylum in Australia. Since 1956, Australia had an asylum-seeker policy, according to which the Departments of External Affairs and Immigration and the Australian Security Intelligence Organisation (ASIO) assessed requests for asylum. ${ }^{13}$

The number of people seeking asylum in Australia during the 1950s and 1960s was comparatively small. Australia's geographical position seemed to ensure that it would never play a significant role as a country of first asylum. Australia itself is - in the words of its national anthem-a country "girth by sea." But until 1975, Australia was a colonial power, and its largest colony and closest neighbour, the then Australian Territory of Papua and New Guinea, shared a land border with first the Dutch colony of West New Guinea, and then Indonesia. In 1962, the Dutch were pressured into withdrawing from New Guinea and effectively surrendered the last remnant of their former Southeast Asian empire to Indonesia. Over the following years, a small but constant trickle of refugees moved across the partly unmarked border into the Australian territory. Between 1962 and 1973, several thousand refugees from the
Indonesian-controlled western half of the island of New Guinea crossed into Papua and New Guinea. ${ }^{14}$

In terms of the contacts between the UNHCR and Australia over these refugees, it is possible to distinguish four phases in this period, which are demarcated by:

- the Dutch withdrawal from West New Guinea in October 1962;

- the first evidence of the UNHCR's interest in the issue of West Papuan refugees in January 1965;

- the appointment of Prince Sadruddin Aga Khan as High Commissioner for Refugees in December 1965;

- the election of a federal Labor government in Australia in December 1972; and

- self-government for Papua New Guinea in December 1973.

\section{Of No Concern to the UNHCR (October 1962-December 1964)}

Even before the Dutch and Indonesian governments agreed on the terms under which the Dutch would leave their last Southeast Asian colony, the Australian government became deeply concerned about the prospect of refugees fleeing from West New Guinea to Papua and New Guinea. In August 1962, Cabinet considered a submission by the Department of External Affairs, which warned of such an influx. ${ }^{15}$ That same month, Australia's Minister for External Affairs, Garfield Barwick, twice referred in Parliament to the prospect that an Indonesian takeover of West New Guinea would result in requests for political asylum. ${ }^{16}$ In January 1963, he summoned the Indonesian ambassador to let him know that he was "greatly concerned by the Papuans who were presenting themselves at the border in considerable numbers-some complaining of ill-treatment by Indonesian officials - others merely apprehensive because of what they had heard of Indonesian conduct." ${ }^{17}$

But despite its concerns about the potential and actual influx of refugees to Papua and New Guinea, the Australian government did then neither brief nor consult the UNHCR. Although during the early 1960s, the UNHCR was widening the scope of its activities by extending the concept of good offices, ${ }^{18}$ it did not seek information from Australia about its handling of the refugee issue in Papua and New Guinea.

In May and June 1963-just after West New Guinea's United Nations interim administration had been replaced by an Indonesian administration-the High Commissioner, Felix Schnyder, made an official visit to Australia. He met the Prime Minister, the Secretary of the Department of External Affairs, and other high-ranking government officials. There is no indication in the archival record that Schnyder raised the issue of West Papuan refugees with the Australian government. It may, of course, be that he was 
simply unaware of the problem. (His staff had not briefed him about it ahead of the visit. $)^{19}$

There is no indication either to suggest that the Australians briefed Schnyder about the West Papuan issue. Australia could have argued that it was under no legal obligation to treat West Papuan asylum seekers as potential Convention refugees. It had signed the 1951 Refugee Convention, but, as mentioned earlier, with the caveat that it only applied to people who had become refugees as a result of events occurring in Europe before 1951. But it had never denied its moral obligation to grant asylum to what it considered to be genuine political refugees, ${ }^{20}$ and-despite its preference for dealing with the ICEM-never questioned the validity of the UNHCR's mandate, which did not single out a particular class of refugees on the basis of when and where the events occasioning their displacement had occurred.

\section{The UNHCR Becomes Involved (January 1965-November 1965)}

On 11 January 1965, the UNHCR's representative for Australia and New Zealand, Alexander McIver, sent a cutting from Sydney's Daily Telegraph about Indonesian repression in West Irian to Paul Weis, the UNHCR's Geneva-based legal adviser, seeking his comments "on the position of the Branch Office and the legal status of the refugees, assuming that a major refugee problem did develop in this immediate area." ${ }^{21}$ Until then, McIver had shown no obvious interest in issues of political asylum generally or in the refugee flow into Papua and New Guinea in particular, although he must have been aware of the latter. His letter was not prompted by the newspaper article (as there had been numerous previous references in the Australian press to the situation in West Irian) but most likely was instigated by his designated successor, Victor Beerman, a Dutch diplomat who already represented UNICEF and other UN organizations in Australia and who would add McIver's role to his responsibilities after McIver's retirement at the end of June 1965 (which effectively meant that the UNHCR scaled down its presence in Australia).

Weis replied that while the 1951 Convention did not apply to West Papuans crossing into the Territory of Papua and New Guinea (because of Australia's reservations), these refugees could be regarded as coming within the High Commissioner's mandate. He also pointed out: "The principle of non-refoulement, i.e. that no bona fide refugee should be returned against his will to a country where he fears persecution, should apply regardless of the Convention status of the persons concerned." Weis suggested that McIver discuss the matter with the Australian authorities. ${ }^{22}$

McIver (probably again nudged by Beerman) did not await Weis's reply. On 2 March 1965, he wrote to the
Department of External Affairs to enquire what the Minister for Territories had meant when, in a newspaper interview, he had emphasized the "need to recognise international Conventions." Did he perhaps refer to the 1951 Refugee Convention? ${ }^{23}$

Not having received a reply from the Australian authorities, but now in possession of Weis's reply, McIver followed up his first letter to External Affairs with another two weeks later. Pretending that Weis's interest had been sparked by an article in a London newspaper (rather than by his own letter), McIver quoted Weis's comments about the UNHCR mandate and refoulement. ${ }^{24}$ Australian officials were anxious to reassure the UNHCR. In reply to McIver's first query, External Affairs Assistant Secretary Bob Furlonger, who had just returned from a posting as Australia's Consul-General in Geneva, said that the Minister for Territories had referred to conventions "only in the sense of 'accepted international practices' and had no specific International Convention in mind." He also acquainted McIver with the government's official line on West Papuan border crossers:

There is at present no refugee problem in New Guinea. Indeed, the word "refugee" is largely inapplicable to the kind of cross border movement that has taken place between West Irian and the Territory of Papua and New Guinea. Those persons who have come across the border have in most cases been resident in the border area, with many of them having tribal connections and tribal lands extending across the border into Papua/New Guinea. Papuans in other categories have in nearly all cases agreed to return to West Irian after discussing their situation with officials of our Administration. Over the last year, only one of these cases involved a request by a Papuan for entry on political grounds. ${ }^{25}$

This representation of the situation, which reflected the official government position that Indonesia could be trusted to safeguard the rights of West Papuans and that they had therefore no reason to flee, ${ }^{26}$ was patently untrue as, in the preceding two-and-a-half years, many people had fled Indonesian-controlled West Irian because they had reason to fear for their safety. Some of them, whose claims to have been persecuted or to fear being persecuted had been supported by the Dutch government, had been allowed to remain in the Australian territory.

On the day he replied to McIver, Furlonger also contacted Australia's representative in Geneva, Brian Hill:

I have no need to labour the question of the delicacy of our relationship with Indonesia in New Guinea and the problems which would be created for us by any ill-considered action, particularly if taken publicly, by the High Commissioner's Of- 
fice. ... It is important that UNHCR appreciate the problems arising from our unique position as a country of Western European background living alongside an Asian country—and a particularly turbulent one at that. ${ }^{27}$

Furlonger's advice could be read as a suggestion that Hill appeal to the High Commissioner and his senior staff (who, with the exception of Schnyder's deputy, Prince Sadruddin Aga Khan, were all of European background) to extend their solidarity as Europeans to the far-flung European outpost in the South Pacific.

Furlonger asked Hill to speak to Schnyder and to Thomas Jamieson, the UNHCR's Director of Operations, about "the refugee question in New Guinea":

[W] expect that no action would be contemplated by the High Commissioner's Office-even in the form of references in UNHCR documents-without the closest consultation with us. I think that Schnyder and Jamieson would appreciate the force of this view; what needs also to be avoided is that people like Weis, who may not realise the political sensitivity of the matter, may take seemingly routine action at a lower level which could be just as embarrassing as action taken with the full knowledge of senior UNHCR people. ${ }^{28}$

Jamieson promised Hill to ensure that there were no references to West Papuan refugees in UNHCR documents and that "officers down the line knew the position." ${ }^{29}$ Jamieson, and possibly Schnyder, were easily cajoled into agreeing to the Australian demands.

It seems to have been at least partly Victor Beerman's achievement that the High Commissioner was nevertheless unable to ignore the refugee issue in New Guinea. In September 1965, Beerman, who had been told by a Foreign Affairs official that the Australian government wanted to "discourage any interest by the U.N.H.C.R. in this matter," 30 but who was apparently unaware of the agreement between Jamieson and Hill, wrote a lengthy memorandum about the refugee issue in New Guinea. His findings must have alarmed his superiors in Geneva. He reported that the Department of Territories "is not burdened by any specific knowledge of the 1951 Convention" and that the Australian government had "no experience with any eligibility procedure for refugees arriving on their territory and asking for (first) asylum." He suspected that the Australian authorities ignored a key principle of international refugee law: "With few exceptions, one gets the impression that refoulement is the general line of conduct followed by the local administration." But he also warned: "the matter has to be handled with the greatest caution; there is no doubt that Canberra rather prefers to hush-hush the whole matter not wanting to further deteriorate its already so difficult relationship with the Indonesia of President Sukarno."31

Schnyder adopted one of Beerman's recommendations, namely, to provide the Australian authorities with an "unofficial demarche" offering the UNHCR's assistance and outlining its position. ${ }^{32}$ On 23 November 1965, Schnyder called in Hill and gave him a typed, unsigned note, which Beerman had helped to draft. By handing Hill an informal note rather than a signed letter to the Australian government under the UNHCR letterhead, Schnyder indicated that he was trying to bend over backwards to accommodate Australian sensitivities. He assured Hill that his approach had not been "prompted by his having received information in any way critical of the Australian Governments [sic] action" in relation to border crossers, and that "any information [the Australian government] might give him would be treated as entirely confidential, that it would not be distributed either within or outside his headquarters." ${ }^{33}$ In the note, the High Commissioner told the Australians that they need not be afraid of involving the UNHCR:

UNHCR would greatly appreciate the receipt of information on the procedures applied to persons belonging to the group in question seeking asylum in the Territory. Such information, as well as information relevant to the number of persons who have sought and who have been granted asylum, would be treated by UNHCR as of a confidential nature to the extent that such treatment would be considered necessary by the Australian Government. ${ }^{34}$

The note did not request the UNHCR's involvement in the refugee determination process, nor a visit by a UNHCR envoy to the Territory.

\section{Sadruddin's Diplomacy (December 1965-November 1972)}

By the time the Australians had agreed on a response to the High Commissioner's request, Prince Sadruddin Aga Khan had succeeded Schnyder. In January 1966, Hill formally briefed the new High Commissioner, repeating the Australian line that the great majority of the border crossers "in no sense can be regarded as refugees." ${ }^{35}$ Sadruddin assented to treating all information provided by the Australian government about the refugee issue in New Guinea as confidential, but was more assertive than his predecessor. He told Hill that "while he had no reason to complain in respect of any decisions taken so far by the authorities in Papua and New Guinea, it was his responsibility to ensure that the cases of asylum seekers were given full consideration."36

In order to meet his responsibility, Sadruddin repeatedly requested Australia's permission for a visit of a senior 
UNHCR emissary to Papua and New Guinea to allow the UNHCR to arrive at an independent assessment of the situation. He tried to convince the Australians of the benefits they would gain by allowing him to corroborate the information they provided to him, saying that under the present arrangements "he had no way of adequately assuring other people that Australia was behaving properly." ${ }^{37}$ A visit by an UNHCR envoy, however, was anathema to the Australian and Indonesian governments. In fact, Sadruddin found it difficult to arrange a visit by the UNHCR legal adviser to Australia to discuss the refugee problem in New Guinea.

Sadruddin also repeatedly offered to assist the Australians in determining whether or not a border crosser could be regarded a mandate refugee, but the Australian government was unwilling to consider any proposals that would have amounted to a direct UNHCR involvement in Papua and New Guinea. Aiming to "create an atmosphere of humanitarian understanding . . . between the country of origin and the country of asylum," 38 he also offered himself as a go-between in Australia's dealings with Indonesia, ${ }^{39}$ but Australia's relationship with Indonesia was sufficiently close to render such mediation unnecessary.

Sadruddin was concerned about how the Australian authorities distinguished between border crossers who needed to be "persuaded" to return to Indonesian territory, and those who were granted five-year permissive residence visas in Papua and New Guinea. He queried the fact that decisions about whether or not border crossers were genuine refugees were made by Australian patrol officers on the spot, and that those who were not deemed to be genuine refugees had no right of appeal. ${ }^{40}$ "If the West Irianese have no good reason for entry, are not of intelligence interest, or are not of political importance, they are to be told ... that they are contravening the immigration laws of the Territory and are to return forthwith," the 1969 edition of the Territory's "Intelligence and Security Manual" stipulated. ${ }^{41}$ While those refugees who were not immediately returned to the border had a reasonable chance of being properly heard, decisions about whether or not somebody might have "good reason for entry" because he or she was a genuine refugee were made after only a cursory interview.

The Australians regularly reminded Sadruddin of the terms of their agreement with him, namely, that the information they provided was confidential and that the High Commissioner was not free to act on it. While Hill and his successor (from June 1969), Max Loveday, made these points subtly, others were less diplomatic. In April 1967, the acting External Affairs secretary, Laurence McIntyre, when providing an update about the situation at the Papua New Guinean border to Sadruddin, wrote in the covering letter: "I trust that no action by your office will be contem- plated without prior reference to us." ${ }^{42}$ Here McIntyre did not refer to a mutual understanding reached between two equals, or, even less, make a request, but rather seemed to remind the High Commissioner of a previous Australian directive. But such frankness was the exception. In fact, Hill and Loveday were able to develop a special relationship with Sadruddin because they accorded him-at least outwardly-respect. ${ }^{43}$

For more than seven years, Sadruddin treated the issue of West Papuan refugees and his communication with the Australian authorities as highly confidential. ${ }^{44}$ On at least two occasions, he reprimanded the UNHCR representative in Australia for drawing the refugee problem in Papua and New Guinea to the attention of other United Nations staff. In July 1967, for example, the UNHCR representative in Macao, the Australian national Bill McCoy, mentioned in a letter to the Geneva headquarters that he had heard that only 10 per cent of the West Papuan asylum seekers were allowed to remain in Papua and New Guinea but that the majority of them had a prima facie case for asylum. ${ }^{45} \mathrm{He}$ was told that "Headquarters is in possession of a fair amount of information on this question," that the matter was highly confidential, and that it was "being dealt with here on the highest level." 46 At the same time, Beerman, who had been identified as the likely source of McCoy's insights, was rebuked for sharing information with McCoy. ${ }^{47}$

The Australian government rejected all suggestions to go beyond the high-level contacts with the High Commissioner. It used references to the exclusivity of these contacts to thwart Sadruddin's attempts to resurrect the position of a full-time UNHCR representative in Australia. ${ }^{48}$ Sadruddin, on the other hand, unsuccessfully tried to extract concessions from the Australian government by referring to the difficulties this exclusivity entailed. Citing reports of refoulement in New Guinea, for example, he told Hill that "members of his Legal Department were pushing him to do something officially on this matter as he would normally do in cases where such allegations had been made publicly" ${ }^{49}$ But all he ever received in return for his discretion were confidential briefings.

\section{A Breakdown in Communication (December 1972-December 1973)}

On 2 December 1972, the Labor Party won the Australian elections. After twenty-three years of uninterrupted conservative rule at the federal level, the election of the Whitlam government represented a seismic shift in Australian politics. In terms of Australia's response to West Papuan refugees, two of the incoming government's commitments were of particular potential relevance: to granting independence 
to Papua New Guinea at the earliest opportunity, and to signing a raft of international conventions, including the 1967 Protocol to the 1951 Refugee Convention.

One year after the election of the Whitlam government, Papua New Guinea was granted self-government, and West Papuan border crossers became the responsibility of the Papua New Guinean government. But even before then, Australia's response to the refugee issue in New Guinea was informed by the idea that Australian policies ought to avoid creating a liability for a future independent Papua New Guinea.

Before December 1972, Sadruddin had on several occasions urged the Australian government to sign the 1967 Protocol to the 1951 Refugee Convention. But the government knew that by doing so, it would have implicitely invited the High Commissioner's involvement in addressing the West Papuan refugee problem, as Article 2 of the Protocol obliges signatories to co-operate with the Office of the High Commissioner in the exercise of its functions and in particular to facilitate the Office's duty of supervising the application of the Protocol. ${ }^{50}$ While it was in principle in favour of signing the Protocol, the Whitlam government's approach did not deviate from that of its predecessor. Australia signed the Protocol only on 2 December 1973, after Papua New Guinea had become self-governing, and then stipulated that it did not apply to Papua New Guinea.

A personnel change proved to be of more immediate consequence for the relationship between Australia and the UNHCR than Whitlam's commitment to signing the 1967 Protocol. The cordial relationship that had existed between Sadruddin and Australia's representative in Geneva and, by extension, the Australian foreign ministry, abruptly ended when, following Labor's victory, Max Loveday was replaced by Laurence Corkery. ${ }^{51}$ Sadruddin was unimpressed when the flow of information from the Australian mission in Geneva to the UNHCR dried up. On 6 March 1973, he told his deputy, Charles Mace: "Please see the Australian Ambassador in my absence and ask him if he has looked up my last letter to Max Loveday and his interim reply-as promised during our meeting of 23. II. 73 ... and ask him AGAIN for a reply to our last demarche. Good luck!"52

While Sadruddin had been dealing with Hill and Loveday, he had often used representations by third parties, such as West Papuan political representatives, to elicit reactions from the Australian government. But he had never substantially responded to such representations beyond acknowledging their receipt. That changed in early 1973. When Sadruddin responded to a letter from Major-General Paul Cullen, who represented both the United Nations Association of Australia and CARE Australia, an umbrella organization of Australian NGOs assisting refugees, he tried to open another channel of communication with Australia, confiding to Cullen that the "Australian authorities keep my Office informed from time to time on the number of persons to whom temporary resident permits are being granted, but this does not necessarily provide a complete solution." ${ }^{33} \mathrm{He}$ also passed on Cullen's concerns to the Australian government; this time, rather than either trying to elicit an Australian response or keeping the Australian government informed of the criticism directed at its policies in New Guinea, Sadruddin used Cullen's letter to underscore his own position.

How the relationship between Australia and the UNHCR had changed became apparent when, in August 1973, Sadruddin directed that the file dealing with protection issues in Papua and New Guinea, which had been for his own and Jacques Colmar's eyes only, should now be made accessible to other senior UNHCR staff. ${ }^{54}$

In 1973, the UNHCR came close to lodging a strong formal protest against Australia's policies in Papua and New Guinea, after the Australian government decided to deport several asylum seekers to Indonesia. But once more, for the price of a comprehensive briefing the High Commissioner agreed to keep quiet. ${ }^{55}$ The three men concerned were deported.

As far as its response to refugees was concerned, the Labor government proved to be no more generous than its conservative predecessors. Its policy in New Guinea and its response to the UNHCR's appeal to resettle more Asians from Uganda belied Whitlam's claim in December 1973 that his government had ensured that "our country has once again assumed its rightful place in the vanguard of countries promoting human rights." 56

\section{Postcript}

\section{(December 1973 to September 1975)}

After 1 December 1973, the UNHCR negotiated with Papua New Guinea rather than with Australia. But the organization tried to use Australia as an intermediary to convince the Papua New Guinean government to sign the Refugee Convention and Protocol and to allow an UNHCR emissary to visit Papua New Guinea. As soon as Australia was no longer directly responsible for West Papuan refugees, it agreed to the proposed visit. ${ }^{57}$ But the government in Port Moresby was as opposed to such a visit as the government in Canberra had been before 1 December 1973. This time, however, the High Commissioner's representations were successful, and in August 1975, for the first time, a senior UNHCR officer was allowed to visit Papua New Guinea. ${ }^{58}$

In his relationship with the Papua New Guinean government, Sadruddin did not observe the discretion that had marked his relationship with the Australians, particularly 
before December 1972. In April 1975, all restrictions on the circulation of the file dealing with West Papuan refugees in Papua New Guinea were removed. ${ }^{59}$

\section{Conclusion}

Until the granting of self-governance to Papua New Guinea in 1973, the Australian government successfully managed to keep the UNHCR effectively out of Papua and New Guinea, and to deal with the border crossers entirely on Australia's own terms-which were often informed by Indonesia's terms. Testament to Australia's and Indonesia's success in keeping the UNHCR sidelined is the fact that Louise Holborn's 1,500-page history of the organization (which was initiated by Sadruddin in the late 1960s and published in 1975) does not once mention West Papuan refugees. ${ }^{60}$

Until the end of 1972, the UNHCR's approach towards the West Papuan refugee problem was marked by the organization's desire to avoid, at all costs, embarrassing the Australian government. The costs were high: by respecting the confidentiality agreement with the Australians, the High Commissioner could not intervene publicly on behalf of West Papuan refugees. Indirectly, such intervention could have made a significant impact: the Australian government was sensitive to criticism of its refugee policies in the Australian and Dutch press and in the House of Assembly in Port Moresby; the High Commissioner may have been able to lend weight to this criticism.

In 1967, the UNHCR representative in Macao was warned off from making further enquiries about West Papuan refugees and told that the Geneva headquarters were already well informed about the issue. But the information available to the High Commissioner was at best one-sided and often poor. None of his staff had ever visited the border region or spoken to West Papuan refugees in Papua and New Guinea. He had to rely on what the Australian government chose to tell him, on newspaper articles, and on statements from West Papuan exiles. Sadruddin became more proactive only from 1973 onwards, when he found that the Australian representative in Geneva could no longer be relied on to keep him informed.

The information provided by Hill and Loveday was of questionable value if only because it had gone through many hands: distilled by the Administrator's office in Port Moresby from reports written by District Officers (which in turn were based on reports compiled by patrol officers and intelligence personnel), and then submitted to the Department of Territories in Canberra, which in turn prepared a summary for the use of the Department of External Affairs. External Affairs officers, who liaised with the UNHCR and the Indonesian government, had themselves often only a sketchy understanding of the conditions in Papua and New Guinea.

Sadruddin's "privileged" access to information needs to be seen also in the context of the substantive briefings provided to the Indonesian government. While he was supplied with statistics, the Indonesians were provided, for example, with a list of names of all permissive residents in Papua and New Guinea, and had occasional access to refugees in holdings camps. ${ }^{61}$ But then, Sadruddin valued the information provided by the Australian government not so much because of what it told him about the situation in New Guinea as for the fact that it supposedly allowed him to be ahead of those criticizing Australia's response (and, by implication, the UNHCR for not censoring that response).

David Forsythe has drawn attention to the need of organizations such as the International Committee of the Red Cross (ICRC) and the UNHCR to rely on discretion rather than on public criticism in accomplishing their objectives. ${ }^{62}$ Discussing the use of discretion by the ICRC, he points out that it is "an instrumental rather than constitutive matter." 63 As such, it ought to have been employed principally to advance the cause of persons of concern to the UNHCR. Yet there is no evidence in the archival record that that was the case. For Sadruddin, the personal relationship with Hill and Loveday, which warranted his discretion, may have become an end in itself. He argued consistently that discretion was necessary to protect Australian interests, and made comparatively few references to the interests of West Papuan refugees. In fact, Sadruddin believed so strongly in the merits of discretion that he exhorted a prominent West Papuan exile to "be discreet in his approaches in order to avoid embarrassing the Australian authorities vis-à-vis the Indonesian government." 64

Schnyder and Sadruddin received little in return for their discretion. To "mollify" 65 them, the Australian government kept them informed, but as they were unable to corroborate the information they received, these briefings were of doubtful value. The UNHCR's demands-for a more transparent refugee status determination procedure and for a fact-finding mission to Papua and New Guinea-were not met. Why, then, did the two High Commissioners agree to the Australian government's terms?

There is no evidence in the archival record to suggest that Australia tried to use its clout as a resettlement country and as a major donor to influence the UNHCR's approach to West Papuan refugees. Australia never intimated that it could cut its funding or direct it only towards specific projects. (At the time, Australia made an untied contribution to the UNHCR.) But it may have been unnecessary for the Australian representatives in Geneva to draw the UNHCR's attention to the support it had lent to the 
UNHCR over the years. "In proportion to its population, Australia has led the world in accepting refugees for resettlement," Louise Holborn points out in her 1975 history of the UNHCR. ${ }^{66}$ In the first twenty-five post-war years, only the United States admitted more refugees for resettlement than Australia. In comparison to the contribution Australia made to resettling European refugees, the refugee issue in New Guinea would have seemed comparatively minor. It may have seemed hardly worth the risk of offending Australian sensibilities. Arguably the High Commissioner was as much a political realist as the Australian government, which was anxious not to offend Indonesian sensibilities. "In the end the fate of several hundred thousand coastal West Papuans is unimportant compared with the friendship of a Government representing 115 million people," the journalist Peter Hastings commented in 1968, thereby summarizing the Australian government's approach to West Irian at the time. ${ }^{67}$

Sadruddin's reluctance to push the issue of West Papuan refugees with the Australian government seems likely to have been shaped also by his attitude towards Indonesia. After the toppling of the Sukarno government, and the ensuing bloodshed and mass displacements in Indonesia, Sadruddin had decided that the UNHCR's intervention would amount to interference in the domestic affairs of a sovereign state. ${ }^{68}$ The Indonesian government was as interested as its Australian counterpart in sidelining the UNHCR over the refugee issue in New Guinea. ${ }^{69}$ Having been prepared to accommodate the interests of the Suharto government in the aftermath of the coup, it made little sense for Sadruddin to then offend Suharto by insisting on the UNHCR's involvement in New Guinea.

Sadruddin's preparedness to accept Australian assurances at face value was probably also informed by his views on West Papuans. In a briefing for Arnold Rørholt, Sadruddin warned that "an over-liberal asylum policy" would create problems both for the Australian authorities and for the UNHCR, and might not be in the interests of the refugees themselves:

Indeed, it is unlikely that these groups can ever be resettled elsewhere since Australia will be most reluctant to accept them on the Australian continent and since other governments would probably adopt the same attitude. West Irian is a very backward area and the inhabitants are most primitive. ${ }^{70}$

In the context of Sadruddin's briefing, this reference reads as if he doubted that people as "primitive" as the inhabitants of West Irian could be anything but economic migrants. Incidentally, his assessment was shared by many officers in the Departments of Territories and External Affairs.
Histories such as the one presented here could be of relevance for at least two basic reasons: because they highlight the legacies of the past and because they draw attention to the exceptionality of the present. A close look at Australia's approach to the UNHCR in the 1950s and 1960s suggests that the skepticism with which the Australian government now regards any UN involvement in Australian affairs has a long tradition, and that rather than being something that developed under the Howard government, it is something that is at least as old as the UNHCR.

But this close look could also highlight the specificity of the current situation. While the Australian government did not consider itself under any international legal obligation in relation to its treatment of West Papuan asylum seekers, it frequently claimed that it acted as if it were under such obligation. In 1971, for example, Loveday assured the High Commissioner "that the Australian Government, while not a party to the Protocol of the Convention on Refugees, is publicly committed to be guided by the principles embodied in the convention and the Declaration on Political Asylum and has consistently honoured this undertaking." 71 Given Australia's unwillingness to sign the Protocol, such statements were somewhat rhetorical. But the fact that they were made nevertheless suggests that the government wanted to appear committed to the principles enunciated in the Protocol-both in terms of its international reputation and in order to satisfy a domestic audience. Nowadays, the government tries to balance its interest in Australia's international reputation with its interest in electoral gain. And it appears that the latter is best served by open disregard for international institutions such as the UNHCR. Nowadays, the UNHCR knows from experience that public criticism of the government's policies affects the amount and nature of the funding it receives from Australia.

The current tensions between the UNHCR and the Australian government are not only the outcome of Australia's refugee and asylum-seeker policies, but also of the UNHCR's public criticism of these policies. The Australian government has responded with public displays of annoyance to what it perceives to be interference in Australian domestic matters. The Howard government has made as few concessions to the UNHCR's public criticism of Australia's mandatory detention policies as it did to Sadruddin's discreet diplomatic efforts to institute a proper eligibility procedure for West Papuan asylum seekers. But the UNHCR's public criticism has heartened the domestic opposition to the government's policies. David Forsythe has pointed out that the UNHCR, unlike the ICRC, does not appear to have "a means for reviewing . . . its practice of discretion-publicity in the past, and hence what might prove useful in the present or future."72 Studies along the 
lines of the one undertaken here may contribute to a better understanding not only of the tactical value of discretion, but also of the comparative benefits of various strategies open to the UNHCR in its dealings with governments.

Finally, this study demonstrates the highly political nature of the UNHCR's involvement. "My constant preoccupation in this matter has been to assist the Australian government in solving a complex humanitarian problem in a non-political way," Sadruddin wrote to the Australian Prime Minister, William McMahon, in $1970 .{ }^{73}$ But the High Commissioner's acquiescence to Australian realpolitik in return for privileged access to information could only be termed non-political if one left the interests of West Papuan refugees out of the equation. A non-political UNHCR is inconceivable - as a reader of Sadruddin's letter to McMahon knew, who queried the above sentence in the margin: "with political refugees seeking political asylum?"74

\section{Notes}

1. Astri Suhrke, "Relations with the Military", in Astri Suhrke, Michael Barutciski, Peta Sandison and Rick Garlock, The Kosovo Refugee Crisis:An Independent Evaluation of UNHCR's Emergency Preparedness and Response (Geneva: UNHCR, Evaluation and Policy Analysis Unit, 2000), 109-16.

2. Gil Loescher, The UNHCR and World Politics: A Perilous Path (Oxford: Oxford University Press, 2001).

3. Ibid., 350 .

4. See, for example, Spencer Zifcak, Mr Ruddock Goes to Geneva (Sydney: UNSW Press, 2003).

5. Klaus Neumann, Refuge Australia: Australia's Humanitarian Record (Sydney: UNSW Press, 2004), 80-82.

6. T. H. E. Heyes to Secretary External Affairs, 22 May 1950, National Archives of Australia, Canberra (hereafter: NAA): A1838 855/11/11 part 2.

7. On the Australian government's approach to the Geneva conference, see Neumann, Refuge Australia, 83-84.

8. United Nations Information Centre for Australia and New Zealand, press release, 21 June 1956, NAA: A1838 861/8/5/3.

9. A. R. Lindt to N. S. Currie, 17 December 1958, NAA: A1838 $861 / 8 / 5 / 3$

10. P. R. Heydon to Minister, 15 January 1959, NAA: A1838 $861 / 8 / 5 / 3$

11. T. H. E. Heyes to Secretary External Affairs, 25 November 1958, NAA: A1838 861/8/5/3.

12. Casey to Heydon, 20 January 1959, on P. R. Heydon to Minister, 15 January 1959, NAA: A1838 861/8/5/3.

13. For Australia's response to asylum seekers in the 1950s and early 1960s, see Neumann, Refuge Australia, 56-64. Australia's asylum seeker policies were put into sharp relief by the asylum requests of three Portuguese sailors in 1961; see Klaus Neumann, "'Stay Puts' and Asylum Seekers in Darwin, 1961-1962: Or, How Three Portuguese Sailors Helped to Undermine the
White Australia Policy," Journal of Northern Territory History, 16 (2005), 1-15.

14. On the movement of refugees from Indonesian-controlled western New Guinea to Australian-controlled eastern New Guinea, see Neumann, Refuge Australia, 65-78; Klaus Neumann, "Asylum Seekers and 'Non-Political Refugees' in Papua and New Guinea," Australian Historical Studies 33, no. 120 (2002), 359-72; June Verrier, "The Origin of the Border Problem and the Border Story to 1969," in Between Two Nations: The Indonesia-Papua New Guinea Border and West Papua Nationalism, ed. Ron May (Bathurst: Robert Brown and Associates, 1986), 18-48; Paul van der Veur, "West Irian Refugees: What Is 'Permissive Residence'?", New Guinea and Australia, the Pacific and South-East Asia 1, no. 4 (1965-1966), 13-19.

15. Garfield Barwick, Cabinet submission no. 330, 19 July 1962; Cabinet decision no. 375 of 6 August 1962, both NAA: A5819 volume 8/agendum 330.

16. Commonwealth Parliamentary Debates (hereafter: $C P D$ ), Representatives, vol. 36, 15 August 1962, 349; CPD, Representatives, vol. 36, 23 August 1962, 752.

17. G. C. Lewis, "Record of conversation-General Suadi and the Minister, on 21st January, 1963”, NAA: A1838 3036/14/1/6 part 1.

18. See Loescher, The UNHCR and World Politics, 109-14.

19. For Schnyder's visit to Australia, see the relevant files of the Prime Minister's Department (NAA: A463 1963/2138), and of the UNHCR head office (Archives of the United Nations High Commissioner for Refugees, Geneva (hereafter: UNHCR Archives): 11,1 6/1/AUSL part 1; 11,1 1/7/5/AUSL/NZ).

20. See, for example, CPD, Representatives 36, 23 August 1962, 752.

21. A. McIver to Paul Weis, 11 January 1965, UNHCR Archives: 11,1 6/1/NG part 1

22. P. Weis to A. McIver, 1 March 1965, UNHCR Archives: 11,1 6/1/NG part 1.

23. A. McIver to Secretary External Affairs, 2 March 1965, NAA: A1838 932/5/14 part 1.

24. P. Weis, quoted in A. McIver to Furlonger, 19 March 1965, NAA: A1838 932/5/14 part 1.

25. Furlonger to McIver, 13 April 1965, NAA: A1838 932/5/14 part 1.

26. See, for example, CPD, Representatives 47, 26 August 1965, 477.

27. Furlonger to B. C. Hill, 13 April 1965, NAA: A10034 225/6/18 part 1.

28. Ibid.

29. B. C. Hill to Furlonger, 29 April 1965, NAA: A10034 225/6/18 part 1.

30. J. H. A. Hoyle, file note, 30 July 1965, NAA: A446 1965/46886.

31. V. A. M. Beerman to High Commissioner for Refugees, 13 September 1965, UNHCR Archives: 11,1 6/1/NG part 1.

32. Ibid.

33. Hill to External Affairs, 23 November 1965, NAA: A6980 S251060.

(C) Klaus Neumann, 2006. This open-access work is licensed under a Creative Commons Attribution-NonCommercial 4.0 International License, which permits use, reproduction and distribution in any medium for non-commercial purposes, provided the original author(s) are credited and the original publication in Refuge: Canada's Journal on Refugees is cited. 
34. Note handed by Felix Schnyder to Brian Hill, 23 November 1965, NAA: A10034 225/6/18 part 1.

35. External Affairs to Australian Consulate-General Geneva, 12 January 1966, NAA: A6980 S251060.

36. Hill to External Affairs, 13 January 1966, NAA: A6980 S251060.

37. Loveday to External Affairs, 5 June 1969, NAA: A10034 225/6/18 part 3.

38. Sadruddin Aga Khan to A. Rørholt, 4 December 1968, UNHCR Archives: 11,1 6/1/NG part 2.

39. G. A. Jockel to D. Anderson, 13 November 1970, NAA: A1838 $3036 / 10 / 2 / 3$ part 1

40. See, for example, Sadruddin Aga Khan to A. Rørholt, 4 December 1968, UNHCR Archives: 11,1 6/1/NG part 2; P. Brazil, "Record of conversation with Dr. A. Rorholt . . 17 December 1968”, NAA: A1838 932/5/14 part 3.

41. Territory of Papua and New Guinea, "Intelligence and Security Manual” (October 1969), p. 8, NAA: A1838 3036/10/2/1 part 1.

42. L. R. McIntyre to Sadruddin Aga Khan, 21 April 1967, UNHCR Archives: 11,1 6/1/NG/PC part 3.

43. In August 1970, Loveday apologised to "dear Sadry" after his office had written to Sadruddin with information about permissive residents: "Their heart was in the right place, as they wanted to pass the information to you straight away, but I am somewhat concerned to see that the letter was signed by a junior officer and gave no explanation why I had not handled the matter personally." (Loveday to Sadruddin, 5 August 1970, UNHCR Archives: 11,1 6/1/NG part 2).

44. He told Hill that he kept all papers relating to West Papuan refugees in his personal safe and did not feel "free to discuss developments with his own staff who naturally refer news items, etc. on this to him while ignorant of the discussions and confidential communications on this subject that have taken place between UNHCR and the Australian authorities" (Hill to External Affairs, 13 July 1967, NAA: A6980 S251060).

45. W. K. McCoy to UNHCR Geneva, 5 July 1967, UNHCR Archives: $11,16 / 1 / \mathrm{NG}$ part 1.

46. A. Rørholt to W. K. McCoy, 24 July 1967, UNHCR Archives: $11,16 / 1 / \mathrm{NG}$ part 1 .

47. J. Colmar to UNHCR Representative Sydney, n.d. (July 1967), UNHCR Archives: 11,1 6/1/NG part 1.

48. B. C. Hill to Secretary External Affairs, 21 January 1969, NAA: A10034 225/6/18 part 2.

49. Hill to External Affairs, 3 October 1968, NAA: A1838 932/4/1 part 20.

50. P. Brazil, "Protocol Relating to the Status of Refugees", 28 November 1968, p. 8, NAA: 3036/10/2/3 part 1; J. H. Greenwell to Administrator, n.d. (October 1973), p. 4, NAA: A1838 $3036 / 10 / 2 / 3$ part 2

51. Sadruddin came to be on first name terms with both Hill and Loveday.

52. Sadruddin to Mace, 6 March 1973, UNHCR Archives: 11,2 600.PNG part 2
53. Sadruddin to Cullen, 21 February 1973, UNHCR Archives: 11,2 600.PNG part 2.

54. Charles H. Mace to O. E. Schulé, 1 August 1973, UNHCR Archives, 11,2 600.PNG part 3.

55. Department of Territories to Administrator, 25 July 1973, NAA: A452 1969/2605; J. L. Lavett, record of telephone conversation with F. A. Bauman, 25 July 1973, NAA: A1838 3036/10/2/3 part 2; L. Corkery to J. L. Lavett, 25 September 1973, NAA: A1838 3036/10/2/3 part 2.

56. Whitlam, address to United Nations Association, 10 December 1973, quoted in Foreign Affairs to Australian Mission New York, 11 December 1973, p. 9, NAA: A1838 3036/10/2/3 part 3. On Australia's response to Asians from Uganda, see Klaus Neumann, "Hard of Heart: A Bipartisan Approach", Australian Financial Review, 28 May 2004.

57. See, for example, Frank A. Bauman to J. D. R. Kelly, 8 March 1974, UNHCR Archives: 11,2 600.PNG part 2.

58. The officer, John Kelly, wrote two reports about his visit: one for the High Commissioner, and one, a sanitised version, which had been requested by the Papua New Guinean government with the aim of forwarding it to the Indonesian ConsulGeneral in Port Moresby. For both reports, see UNHCR Archives: 11,2 600.PNG part 3 .

59. Georges Koulischer to Schulé, 14 April 1975, UNHCR Archives: 11,2 600.PNG part 3 .

60. Louise W. Holborn, Refugees: A Problem of Our Time: The Work of the United Nations High Commissioner for Refugees, 1951-1972, 2 vols. (Methuchen: Scarecrow Press, 1975).

61. Anderson to Minister, 2 August 1972, NAA: A1838 3036/ 10/2/1 part 2. The statistics compiled by the Department of Territories were of doubtful value; see Neumann, "Asylum Seekers", 364n.19.

62. David Forsythe, "UNHCR's Mandate: The Politics of Being Non-Political" (Working Paper No. 33, New Issues in Refugee Research, Geneva, March 2001), 16-22.

63. Ibid., 17.

64. A. Rørholt, file note, 13 July 1967, UNHCR Archives: 11,1 6/1/NG part 1.

65. Max Loveday used this term to describe the rationale for briefing Sadruddin (Loveday to External Affairs, 5 July 1969, NAA: A6980 S251060).

66. Holborn, Refugees: A Problem of Our Time, vol. 1, 622.

67. Peter Hastings, "West Irian Refugees Put NG on Spot", Sydney Morning Herald, 30 August 1968.

68. Loescher, The UNHCR and World Politics, 145-46.

69. See, for example, Australian embassy Djakarta to External Affairs, 21 April 1970, NAA: A6980 S251060.

70. Sadruddin Aga Khan to A. Rørholt, 4 December 1968, UNHCR Archives: 11,1 6/1/NG part 2.

71. H.M. Loveday to Charles Mace, 22 June 1971, UNHCR Archives: 11,2 600.PNG part 1.

72. Forsythe, "UNHCR's Mandate", 18.

73. Sadruddin to McMahon, 8 April 1970, NAA: A452 1969/2605.

74. Ibid., Marginal note. 
Klaus Neumann is a senior research fellow at the Institute for Social Research, Swinburne University of Technology, Melbourne. He is the author of Refuge Australia: Australia's Humanitarian Record (2004), and is currently working on a comprehensive history of Australian public policy responses to refugees and asylum seekers, and on a book about the White Australia policy. Research for this article has been supported through a Swinburne University special initiatives grant. are credited and the original publication in Refuge: Canada's Journal on Refugees is cited. 